\title{
TEACHING READING COMPREHENSION USING PRE-VIEWING TECHNIQUE
}

\author{
Neng dewi \\ IKIP Siliwangi \\ Dewirosmiati84@gmail.com
}

\begin{abstract}
Reading is one of the basic communicative skills, but it has very complex process. It can be said that reading is a process in which the reader gets message from the author in the written from. The objectivities of this research entitled "Teaching Reading Comprehension Using Previewing technique" was to find out whether or not the previewing as pre reading technique can improve students' reading comprehension. The population was all the students grade XI of Ma Muslimin Cijenuk in the academic years 2017-2018, while the sample of this research was 34 students of XI science established through random technique. The Research used quantitative method. The instruments used in this research were pretest and posttest. The techniques in analyzing the data were using SPSS version 21 . The result of data analysis showed that the value of the t-value is 21.185 is bigger than t-table at level 5\% 2.042, it means that the hypothesis null is rejected. The results of the study show that teaching reading using previewing technique in second grade of MA Muslimin Cijenuk is able to improve students' reading comprehensions.
\end{abstract}

Keywords: Reading Comprehension, Previewing Technique

\section{INTRODUCTION}

Reading is one of the basic communicative skills, but it has very complex process. It can be said that reading is a process in which the reader gets message from the author in the written from. In this case reading can be said as an interactive process. Because while reading, a reader guesess, Predicts, checks and asks questions about what the text is.

To comprehend the text, the students need some motivation, background of knowledge, some strategies and skills. Students may fail to comprehend the texts when researching text. As it is explained by (Lazar, 1993) groups such problems as motivation, comprehension, making interpretations, and inadequate reading strategies. Are kinds of failure which occur, because of the lack of appropriate knowledge structures. Motivating, comprehend, making interpretations and inadequate reading strategies, those kinds is important strategies which have to had for students if they want appropriate knowledge structures.

(Grabe. \& Stoller, 2002) explains that reading comprehension is the interaction of information between the reader's drawing information from a text and the reader's expectations or information about the text that already has while learn concluded that reading comprehension is not static competency. 
According to (Tompkins, G, 2010) there are five stages in reading process: prereading, reading, responding, exploring, and applying. Those five stages it is very important to make the student comprehend the text. According to (Chastain, 1998) the purpose of pre-reading activities is to motivate the students to read the assignment and to prepare them to be able to read it. To motivate the students for reading Pre-reading activities is one of the way because pre-reading activities making the students have motivate to read and do it the assignment and pre-reading activities making the students ready to be able read the text.

Previewing as pre-reading activity. Previewing the text by using the title, pictures, illustrations, or subtitles of a text as stimuli, can help students predict or make some educated guesses about what is in the text and thus activate effective top-down processing for reading comprehension. Through this process, the teacher moves students from memorizing information to meaningful reading activity and begins the process of connecting reading activity rather than remembering bits and pieces.

One type of pre-reading strategy is previewing.According to (Silberstein, 1994) previewing techniques have benefits that allow students to formulate hypotheses about text. According to (Mikulecky, 2003) previewing before read can make a big difference in how well the reader understand what the reader read, the aim of previewing is to find out what the reader are going to be reading before the reader actually read.

\section{METHOD}

The research was the second grade of Ma Muslimin Cijenuk which has two classes there are xi m2ia which consist of 34 students and $x i$ iis which consist of 34 students and the total population is 68 students. And sample of the research was xi Mia of Ma Muslimin Cijenuk in academic 2017-2018 which consist of 34 students It is established through the simple random sampling technique.

The writer use quantitative method to collect the data as. According to (Kaswan and Suprijadi, 2016) quantitative research is a deductive theory-based research process that focuses primarily on testing theories and specific research hypotheses that consider finding differences and relationships using numeric data and statistical methods to make conclusion specific about the phenomena".

In this research the writer use pre-experimental research. the writer use one group pretestposttest design. The writer computed the averages score of pretest and posttest to see whether this method give significant result to increase of student reading skill, then the average score pretest and posttest were compared.

The design of one group pretest-posttest described below:

$\begin{array}{ccc}\text { Pretest } & \text { Treatment } & \text { Posttest } \\ \text { T1 } & \mathrm{x} & \mathrm{T} 2\end{array}$

To find out the research of the investigation, the writer used standardized test which is defined " the test has been designed so that procedure for administering the test, the materials used in the test, and the way in which the test is scored are constant"( Crowl ,1996:114 in kaswan and supriadi,2016).

The test that the writer given are pretest and posttest which consist of 30 questions reading of multiple choice with the different theme, pretest did at the first meeting on 19 Februari 2018 performed to 34 students of XI science Ma Muslimin Cijenuk and posttest did after the sample 
had apply all the treatment and the posttest held on 02 April 2018 performed to 34 students of XI science Ma Muslimin Cijenuk.

In data collection the writer used pretest and posttest.

a.Pretest

The writer gave the pretest to the students in a form of reading test with 30 questions of multiple choice.

b.Treatment

The writer used previewing technique as the treatment which the technique is to find the main idea about the text and find out what the students are going to read before the students actually read. and the treatments were given 5 times on five meeting. It is shown on table 3.1

\section{Table 3.1}

\begin{tabular}{|c|c|c|}
\hline Treatment & Day Date & Method \\
\hline 1 & 26 February 2018 & $\begin{array}{l}\text { Learners identify characters from } \\
\text { analytic exposition text with theme } \\
\text { environment and the learners follow } \\
\text { steps of previewing technique in } \\
\text { analyzing analytic exposition text. }\end{array}$ \\
\hline 2 & 5 March 2018 & $\begin{array}{l}\text { Students understand the function of } \\
\text { analytical exposition text with theme } \\
\text { environment through pre viewing } \\
\text { technique }\end{array}$ \\
\hline 3 & 12 March 2018 & $\begin{array}{l}\text { The researcher give the different theme } \\
\text { of analytical exposition text is theme of } \\
\text { health and the learners analysis the text } \\
\text { using pre viewing technique }\end{array}$ \\
\hline 4 & 19 March 2018 & $\begin{array}{l}\text { with the same theme on third meeting } \\
\text { researcher provide a simple training in } \\
\text { writing the structure of the analytical } \\
\text { exposition text }\end{array}$ \\
\hline 5 & 26 March 2018 & $\begin{array}{l}\text { with the theme of entertainment of the } \\
\text { text analytical exposition the learners } \\
\text { analysis the text using pre viewing } \\
\text { technique follow instruction of the } \\
\text { researcher }\end{array}$ \\
\hline
\end{tabular}

\section{c. Posttest}

The posttest was given to measure students progress after receiving the treatment, and the writer gave the posttest of the students with the same kind of difficulties of pretest with the different theme, the test is consist of 30 question reading of multiple choice.

d.How to score posttest

The score of posttest taken from each number of the questions was given 3.3. It means if the students answer are all correct he get score 99 and the score is rounded to 100. 


\section{RESULTS AND DISCUSSION}

\section{Results}

The data of students' pretest and posttest score was described in the following table

There are the differentiate students' scores before and after they were given the treatment, the smallest score pretest was 45 and the highest score was 66 and the smallest posttest was 65 and the highest score was 83 , there is a very significant difference between before and after they get the treatment.

The scores of the pretest and posttest above were input to the SPSS computer program. Then the researcher wanted to know mean and standard deviation from the data. It can be see in table 4.2

\begin{tabular}{|c|c|c|c|c|}
\hline \multicolumn{5}{|c|}{$\begin{array}{c}\text { Table } 4.2 \\
\text { Descriptives }\end{array}$} \\
\hline & & & Statistic & Std. Error \\
\hline \multirow{13}{*}{ Pretest } & Mean & & 57.56 & .832 \\
\hline & $95 \%$ Confidence Interval for & Lower Bound & 55.87 & \\
\hline & Mean & Upper Bound & 59.25 & \\
\hline & $5 \%$ Trimmed Mean & & 57.76 & \\
\hline & Median & & 57.50 & \\
\hline & Variance & & 23.527 & \\
\hline & Std. Deviation & & 4.850 & \\
\hline & Minimum & & 45 & \\
\hline & Maximum & & 66 & \\
\hline & Range & & 21 & \\
\hline & Interquartile Range & & 5 & \\
\hline & Skewness & & -.545 & .403 \\
\hline & Kurtosis & & .581 & .788 \\
\hline \multirow{13}{*}{ Posttest } & Mean & & 75.56 & .885 \\
\hline & $95 \%$ Confidence Interval for & Lower Bound & 73.76 & \\
\hline & Mean & Upper Bound & 77.36 & \\
\hline & $5 \%$ Trimmed Mean & & 75.78 & \\
\hline & Median & & 77.00 & \\
\hline & Variance & & 26.618 & \\
\hline & Std. Deviation & & 5.159 & \\
\hline & Minimum & & 65 & \\
\hline & Maximum & & 83 & \\
\hline & Range & & 18 & \\
\hline & Interquartile Range & & 7 & \\
\hline & Skewness & & -.865 & .403 \\
\hline & Kurtosis & & -.435 & .788 \\
\hline
\end{tabular}


From the result which obtained by SPSS showed the mean of pretest was 57.56 and mean of posttest was 75.56 and The result of the standard of pretest was 4.85 and standard deviation of posttest was 5.15

\section{finding out the t-observed by using t- test formula}

a. Testing normal distribution the researcher tested the normally by using one sample Shapiro-Wilk test. this test was chosen because this test was matched for more than 30 samples.

\begin{tabular}{|c|c|c|c|c|c|c|}
\hline \multicolumn{7}{|c|}{$\begin{array}{c}\text { Table } 4.3 \\
\text { Tests of Normality }\end{array}$} \\
\hline & \multicolumn{3}{|c|}{ Kolmogorov-Smirnova } & \multicolumn{3}{|c|}{ Shapiro-Wilk } \\
\hline & Statistic & Df & Sig. & Statistic & Df & Sig. \\
\hline Pretest & .139 & 34 & .096 & .961 & 34 & .253 \\
\hline Posttest & .198 & 34 & .012 & .876 & 34 & .071 \\
\hline
\end{tabular}

From information above, it was know that the value of significant (sig) for both variable in Shapiro-Wilk test were more than 0.05 . As condition of data distribution can be assumed normal if the value is bigger than standard significance $(0,253>0,05,0,071>0,05)$, it can be conducted. Thus, the researcher was able to find out the t-observed by using t-test formula.

b. Computing t-test by paired sample t-test

Table 4.4

Paired Samples Test

\begin{tabular}{|c|c|c|c|c|c|c|c|c|c|}
\hline & & \multicolumn{5}{|c|}{ Paired Differences } & \multirow[t]{3}{*}{$\mathrm{t}$} & \multirow[t]{3}{*}{$d f$} & \multirow{3}{*}{$\begin{array}{l}\text { Sig. (2- } \\
\text { tailed) }\end{array}$} \\
\hline & & \multirow[t]{2}{*}{ Mean } & \multirow[t]{2}{*}{$\begin{array}{l}\text { Std. } \\
\text { Deviati } \\
\text { on }\end{array}$} & \multirow[t]{2}{*}{$\begin{array}{l}\text { Std. } \\
\text { Error } \\
\text { Mean }\end{array}$} & \multicolumn{2}{|c|}{$\begin{array}{c}95 \% \text { Confidence } \\
\text { Interval of the } \\
\text { Difference }\end{array}$} & & & \\
\hline & & & & & Lower & Upper & & & \\
\hline Pair 1 & $\begin{array}{l}\text { pretest - } \\
\text { posttest }\end{array}$ & -18.000 & 4.954 & .850 & $\begin{array}{r}- \\
19.729\end{array}$ & $\begin{array}{r}- \\
16.271\end{array}$ & $\begin{array}{r}- \\
21.185\end{array}$ & 33 & .001 \\
\hline
\end{tabular}

From information above it was know that t observed was 21.185 degree of freedom was 33 , and significance by 2 tailed was $0,001(0,001<0,005=$ the difference between two variable was significant).

Calculating the number of degree of freedom (df) and criticl value of t-table at $5 \%(0,05)$ level of significance with the degree of freedom

After t-observed and degree of freedom were known, the researcher compared them with ttable. The critical value of t-table at the 0.05 level of the significance with the degree of freedom 33 (2 tailed) was 2.042 
With the $\mathrm{df}=34-1=33$, at $\mathrm{p}=0.05$ of 2 tailed, the critical value of $\mathrm{t}$ is 2.042 , as the value of the derived t-observed which showed from the result of SPSS calculation, is bigger than critical ttable $(21.185>2.042)$, and the significance 2 tailed was $0.01(0.01<0.05)$, stating that there is a significant difference between posttest and pretest scores in the result through teaching reading comprehension using previewing technique to the second grade of Ma Muslimin Cijenuk. This means that Null Hypothesis (H0) is rejected. Thus, using previewing technique is effective in improving students reading comprehensions at second grade Ma Muslimin Cijenuk and has significantly successful.

\section{Discussion}

In this section the writer discussed the problem statement put forward in the first chapter. There is one problem stated in that chapter. To remind us the research question, it was stated below. "Can the use of previewing technique improve students' reading comprehension?"

The research began with giving the pretest which consist of 30 questions reading of multiple choice and the smallest score was 45 and the highest score was 66, after the research giving the pretest the research continued by giving treatments using previewing technique and the treatments were giving 5 times, after treatment is completed the research giving test as posttest which consist of 30 questions reading of multiple choice with the different theme with the same difficulty level, and the smallest score was 65 and the biggest score was 83 , there is a very significant difference between before and after the treatments.

The differences of teaching reading comprehension before using previewing technique and after using previewing technique are caused by difference of assessment process at the class.

From the result above, the writer summarized that use of teaching reading comprehension using previewing technique could be applied in teaching reading comprehension because there is a significant difference students' scores before and after using previewing technique. It is shown by the value of derived $\mathrm{t}(\mathrm{t} 0)$ is greater than the critical $\mathrm{t}(\mathrm{t}$-table) $(21,185>2,042)$. It indicates that the null hypothesis is rejected. As a result, there is significant difference between the pretest before getting the treatment and posttest after getting the treatments.

Therefore, it can be conducted that previewing technique is effective in teaching reading. From the explanation above, the writer concluded that in this research the use previewing can improve students' reading comprehension.

\section{CONCLUSION}

After processing and analyzing the data, the writer concludes teaching reading using previewing technique in second grade of MA Muslimin Cijenuk is effective to improve students' reading comprehensions. That are conclusion was supported by the value of the t-value is 21,185 is bigger than t-table at level 5\% 2,042, it means that the hypothesis null is rejected. According to data above, it show that there is a significant increase of teaching reading using previewing technique.

\section{ACKNOWLEDGMENTS}

The writer would like to express thanks to our lecturer for all advices, guidance, and corrections during the completion of this paper.

\section{REFERENCES}

Chastain. (1998). Bibliography of Language Learning Resources. Sil international. 
Grabe., \& Stoller. (2002). Teaching and Researching Reading. Hongkong: City of University Hongkong.

Kaswan and Suprijadi, D. (2016). Research in English Language Education. bandung: Putra Praktisi.

Lazar, G. (1993). Literature and Language Teaching: A Guide for Teachers and Trainers. Cambridge University press.

Mikulecky, B. (2003). More Reading Power: Reading for Pleasure, Comprehension Skills, Thinking Skills, Reading Faster (Second Edition) 2nd Edition. Pearson ESL.

Silberstein. (1994). Techniques And Resources In Teaching Reading. New York: Oxford University Press.

Tompkins, G, E. (2010). Language arts: content and teaching strategies Sampul Depan. Maxwell Macmillan Canada. 